\title{
The inheritance of female colour polymorphism in Ischnura genei (Zygoptera: Coenagrionidae), with observations on melanism under laboratory conditions
}

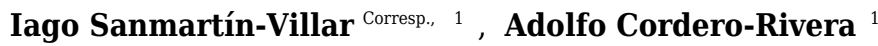 \\ ${ }^{1}$ ECOEVO Lab, Universidade de Vigo, Pontevedra, Galiza, Spain \\ Corresponding Author: lago Sanmartín-Villar \\ Email address: sv.iago@uvigo.es
}

Current research on female colour polymorphism in Ischnura damselflies suggests that a balanced fitness trade-off between morphotypes contributes to the maintenance of polymorphism inside populations. The genetic inheritance system constitutes a key factor to understand morph fluctuation and fitness. Ischnura genei, an endemic species of some Mediterranean islands, has three female colour morphs, including one androchrome (malecoloured) and two gynochromes. In this study, we reared two generations of I. genei under laboratory conditions and tested male behavioural responses to female colour morphs in the field. We recorded ontogenetic colour changes and studied morph frequency in three populations from Sardinia (Italy). Morph frequencies of laboratory crosses can be explained by a model based on an autosomal locus with three alleles and sex-restricted expression, except for one crossing of 42 families with unexpected offspring. The allelic dominance relationship was androchrome $>$ infuscans $>$ aurantiaca. Old individuals reared in the laboratory exhibited different levels of melanism in variable extent depending on sex and morph. Results of model presentations indicate a male preference for gynochrome females and the lack of recognition of androchromes as potential mates. Aurantiaca females were the most frequent morph in the field (63-87\%). Further studies in other populations and islands are needed to understand the maintenance of this polymorphism. 
7 Abstract

8

\section{Abstract}

\section{The inheritance of female colour polymorphism in Ischnura genei (Zygoptera:}

$$
\text { Coenagrionidae), with observations on melanism under laboratory conditions }
$$

Iago Sanmartín-Villar; Adolfo Cordero-Rivera

ECOEVO Lab, E. E. Forestal, Universidade de Vigo, Campus A Xunqueira 36005, Pontevedra, Galiza - Spain

Corresponding author: Iago Sanmartín-Villar.sv.iago@uvigo.es

Current research on female colour polymorphism in Ischnura damselflies suggests that a balanced fitness trade-off between morphotypes contributes to the maintenance of polymorphism inside populations. The genetic inheritance system constitutes a key factor to understand morph fluctuation and fitness. Ischnura genei, an endemic species of some Mediterranean islands, has three female colour morphs, including one androchrome (male-coloured) and two gynochromes. In this study, we reared two generations of $I$. genei under laboratory conditions and tested male behavioural responses to female colour morphs in the field. We recorded ontogenetic colour changes and studied morph frequency in three populations from Sardinia (Italy). Morph frequencies of laboratory crosses can be explained by a model based on an autosomal locus with three alleles and sex-restricted expression, except for one crossing of 42 families with unexpected offspring. The allelic dominance relationship was androchrome $>$ infuscans $>$ aurantiaca. Old individuals reared in the laboratory exhibited different levels of melanism in variable extent depending on sex and morph. Results of model presentations indicate a male preference for gynochrome females and the lack of recognition of androchromes as potential mates. Aurantiaca females were the most frequent morph in the field (63-87\%). Further studies in other populations and islands are needed to understand the maintenance of this polymorphism. 
24 Keywords: colour changes, phenotype, fecundity, reared generations, laboratory effects,

25 Odonata. 


\section{Introduction}

Phenotypic variability is biologically important because it increases adaptive opportunities, and provides a potential avenue for speciation. This kind of variability could be promoted by plasticity (e.g. Radwan (1993)) or be inherited (e.g polymorphism). Polymorphism occurs when alternative intra-population morphs are found at higher frequencies than expected by mutations alone (Ford, 1957). Colour polymorphism is a common phenomenon in the Odonata, particularly in coenagrionids where females exhibit different colour morphs (Cordero \& Andrés, 1996;

Fincke et al., 2005). The maintenance of this kind of phenotypic variability suggests a balance between the costs and benefits of each phenotype based on different mechanisms of frequencyand/or density-dependent selection (Roulin \& Bize, 2007). The adaptive significance of female body colour variation is currently interpreted as an evolutionary response to male reproductive harassment. In this scenario, each female colour morph is balanced by different costs and benefits across fluctuations in the intensity of male harassment, which is frequency-dependent (Van Gossum, Sherratt \& Cordero-Rivera, 2008). In all polymorphic Coenagrionid species so far studied, one of the female morphs presents similar body colouration as the conspecific male (androchrome) and other/s show a different colour (gynochromes). This variation is controlled by one autosomal locus with 2-3 alleles and sex-restricted expression, where only females show colour morphs (Johnson, 1964, 1966; Cordero, 1990; Andrés et al., 1999; Sánchez-Guillén, Van Gossum \& Cordero-Rivera, 2005). However, the dominance of these alleles does not follow a single mechanism among species (including those of the same genus). The androchrome allele is recessive in Ischnura damula (Johnson, 1964), I. demorsa (Johnson, 1966), and Ceriagrion tenellum (Andres et al., 1999); has been suggested to be recessive in Ischnura senegalensis 
48 (Takahashi et al., 2014); but is dominant in Ischnura graellsii (Cordero-Rivera, 1990) and I.

49 elegans (Sánchez-Guillén, Van Gossum \& Cordero-Rivera, 2005).

50 The island bluetail damselfly, Ischnura genei (Rambur, 1842), is a species restricted to

51 Mediterranean islands (Tuscan archipelago and the Tyrrhenian and Maltese islands) (Boudout,

52 2015). This species cohabits with I. elegans in Giglio Island (Boudout, 2015) where both might

53 hybridize (see Sánchez-Guillén et al., 2013c). For some time, I. genei was considered a

54 subspecies of I. elegans, but currently it is considered as a valid species (Dumont, 2013).

55 Nevertheless, very little is known about its biology, and basic information remains undescribed,

56 like its ontogenetic colour change and the inheritance of its colour morphotypes.

57 In this paper, we test the prediction that the maturation and inheritance of the colour

58 polymorphism of I. genei should be similar to its closest relatives (I. graellsii and I. elegans) and

59 that the dominance of the alleles that determine its polymorphism follows the rule androchrome $>$

60 infuscans $>$ aurantiaca. Infuscans and aurantiaca represent the gynochrome morphs (olive to

61 brown and orange-brown without humeral stripe when immature, respectively). We named the

62 morphs using the terminology of I. graellsii to avoid confusing terms as in I. elegans, in which

63 the same morph was named differently according to its age (rufescens, infuscans-obsoleta, or

64 rufescens-obsoleta; e.g. Sánchez-Guillén et al., 2011; Van Gossum et al., 2011).

66 Material and methods

67 Rearing process

68 Six androchromes, five infuscans and nine aurantiaca females (Parental generation (P), N=20)

69 were captured while in copula on 19 and 24 of August of 2011 from Riu Mannu, near Tula

70 (Sardinia - Italy; see Table 4 for coordinates). After mating, females were placed in cups with 
71 wet filter paper to obtain their eggs. Clutches were thereafter maintained in water and checked

72 daily to record hatching date. Larvae were reared in the laboratory in accordance with the

73 previously described methodology (Van Gossum et al., 2003; Piersanti et al., 2015).

74 Two generations of I. genei were raised in the laboratory. Data from females with the

75 identification codes K, S and T (see Table 1) were excluded because they produced a very low

76 number of offspring. Two additional females ( $\mathrm{F}$ and $\mathrm{R}$ ) also produced too few offspring and

77 proportions could not be tested, but their progeny were used as parents in the next generations.

78 One month after hatching, $947 \mathrm{~F}_{1}$ larvae (field-collected females' offspring) were kept

79 individually in small plastic cups and then transferred to cells of ice cube trays with a plastic net as the bottom. This structure allowed for the change of water in groups, the supply of continuous oxygen via an air pump (one for every three ice cube trays), and the elimination of debris by gravity. To prevent the mix of larvae, cells were not completely filled. Spring water was used. Larvae were fed daily ad libitum with Artemia nauplii.

Final instar larvae were transferred to individual $1 \mathrm{~L}$ plastic containers filled with $250 \mathrm{~mL}$ of water. A wooden cooking stick (length $=20 \mathrm{~cm}$, diameter $=0.33 \mathrm{~cm}$ ) was placed inside containers as a substrate for metamorphosis. A net covering the container prevented the escape of adults and supported the wooden stick. After metamorphosis, all water was removed to avoid drowning the newly emerged adults. One day after metamorphosis, imagoes were moved into wooden insectaries $(50 \times 50 \times 50 \mathrm{~cm})$. A glass covered the top and the upper third frontal side of the insectaria. Interior wooden surfaces of the insectaries were covered with aluminium foil, which prevents escape because damselflies perceive the foil's reflectance as the brightness of an open area and thus avoid it (Johnson, 1965). Wooden sticks, fine branches, and nets glued to the top of the insectary provided perches to enrich the environment and limit agonistic interactions. The 
94 insectaries were illuminated by sunlight from laboratory windows and one $60 \mathrm{~W}$ incandescent

95

96

97

98

\section{4}

bulb positioned $10 \mathrm{~cm}$ above each insectary. Adult damselfiles were fed adult Drosophila melanogaster flies. A constant supply of flies was maintained by having a bottle with food and egg-laying substrate for the flies in each insectary. A container of water covered with a net was introduced to increase humidity inside the insectary. A maximum of 10 imagoes lived together in each insectary. Individuals in the insectaries were separated to prevent reproductive or agonistic interactions, taking into account sex and age (according to their maturation colour).

The second generation was obtained from 28 laboratory matings and reared under the same conditions. Four new wooden insectaries, similar to those previously described but with transparent plastic panels instead of glass, were also employed.

Parental genotypes of $\mathrm{P}$ and $\mathrm{F}_{1}$ were inferred based on the phenotypes of their offspring. Herein we follow the notation of Cordero (1990) for the polymorphism locus (p) and each allele: androchrome $\left(\mathrm{p}^{\mathrm{a}}\right)$, infuscans $\left(\mathrm{p}^{\mathrm{i}}\right)$ and aurantiaca $\left(\mathrm{p}^{\mathrm{o}}\right)$.

\section{Fecundity and fertility of field-collected females}

One month after the last larval hatch, eggs laid by field females were counted under a binocular microscope. Fecundity was measured as the total number of eggs laid. Unhatched eggs without an embryo were considered sterile, whereas those that had an embryo inside but did not hatch were considered fertile, because the paper used as oviposition substrate might have impeded some larvae from hatching. These numbers were used to calculate fertility.

\section{Colour maturation}


116 Photographs were periodically taken to have a record of the thorax and eighth abdominal

117 segment (S8) colourations.

118

119 Female morph frequencies in the field

120 The proportion of female morphs was estimated by counting adults from three populations in

121 2008, 2011, and 2012 on the island of Sardinia (Italy). Adults were captured, and their sex, age,

122 and morph were recorded. All were marked to avoid counting them twice, and then released at

123 the place of capture.

124

125

Morph choice by males

126 The androchrome females of this species were identical to males in body colouration and

127 ontogenetic colour changes (see Results). In August 2012, we studied the population from Riu

128 Mannu to test whether males are able to distinguish androchrome females from males and

129 whether males have a preference for gynochromes. The experiment followed the protocol of

130 previous studies (Cordero, Santolamazza-Carbone \& Utzeri, 1998), but used only live models to

131 take into account behavioural differences. Models were mature males or females tethered to a

132 wooden stick using a fine wire, which allowed them to fly. Models were presented to males by

133 approaching them and leaving the model to perch near the focal male. The behaviour of test

134 males was scored as no response, approach to the model, attempt to grasp the model in tandem,

135 and tandem. The order of model presentation was chosen randomly in the first trial and repeated

136 in subsequent trials. Each model was used until 10 males responded. Males that did not respond

137 (5-7 for each individual model) were excluded from the analyses. Whenever possible, each male

138 was marked to avoid testing it twice. Three models were used for each phenotype. 
140 Statistical methods

141 Hatching time for eggs from the P generation were analysed using a Kruskal Wallis test. We

142 used ANOVA to determine whether androchrome and gynochrome females differed in fecundity.

143 Fertility proportions were analyzed using a GLM with binomial errors, corrected for

144 overdispersion. Morph was the only factor entered in both analyses. In the inheritance

145 experiment, the observed frequencies of phenotypes were compared with the expected

146 frequencies using a Chi square test. Some infuscans and androchromes died before sexual

147 maturation and could not therefore be assigned to a morph (all aurantiaca females can be easily

148 identified since emergence). In the second generation, we estimated how many of these females

149 might be infuscans or androchromes, based on the proportion of these morphs in the remaining

150 females of each family. No statistical analyses were performed on progenies where only one

151 morph was expected and found. Sex-ratio differences between morph offspring were analysed by

152 GLM with binomial errors and Tukey test. Male behaviour towards models was analysed by a

153 logistic regression, with model phenotype and model identity (each specimen used in the

154 experiment) entered as predictor variables. Only six males were able to get the model female in

155 tandem (out of 120 tested). Therefore, we used a binomial response variable: approach versus

156 tandem (including tandem attempts and successful tandems). Data were analysed with the

157 statistical package R version 3.2.3 (www.r-project.org), Genstat $18^{\text {th }}$ edition (www.vsni.co.uk)

158 and with xlStat 2016 (www.xlstat.com).

159

160 Results

161 
162 Fecundity and fertility of field-collected females

163 There were no differences among female morphs in egg hatching time $(H=4.61, p=0.100)$, in

164 the number of eggs laid $(\mathrm{F}=1.03, \mathrm{p}=0.322)$, or in the proportion of fertile eggs (GLM with

165 binomial errors, deviance ratio $=1.20, \mathrm{p}=0.324$, Table 1 ).

166

167 Colour morphs and maturation

168 Mature field-collected females showed three colour phenotypes (Figure 1), equivalent to the

169 morphs described for I. elegans (Sánchez-Guillén, Van Gossum \& Cordero-Rivera, 2005) and I.

170 graellsii (Cordero, 1990).

171 One day after emergence males presented a range of green colours, tending toward green-yellow,

172 in the thorax. The thoracic green colour became darker with the maturation process and turned to

173 blue in older individuals (Figure 2).

174 Different thorax colours were observed in androchrome females one day after their emergence 175 [pink (more frequent), sky blue, or green-yellow; Figure 2]. Pink individuals became sky blue 176 between one and three days after emergence. Greenish females were found in the progeny of 177 female 412 (six out of 18 females) and 499 (one out of three). Three days after emergence, 178 androchromes showed a similar body colour to males (Figure 2).

179 The thorax of immature infuscans females was violet and the light-coloured antehumeral stripe 180 was usually wider than in males and androchromes (Figure 2). The thorax of mature infuscans

181 females was olive-green but then turned brownish at old age (more than ten days after their 182 emergence). Most infuscans females showed a variable black spot on the eighth abdominal 183 segment. 
184 Immature aurantiaca females presented pale orange and pink thorax after emergence, with one 185 medio-dorsal black stripe, and no black humeral stripes. Orange individuals became pink two 186 days after emergence. Thoracic pink colour turned greenish or brown around five days of age 187 (Figure 2), and dark brown humeral stripes developed. These two alternative colours (green or 188 brown), observed both in the laboratory and in the field, remained until death, showing different 189 processes of darkening and no transitions between them. This suggests that there are two mature 190 colours in the aurantica morph. In one case, the brown colour of the brownish individuals

191 covered the thoracic dorsolateral region, with only the metepimeron remaining light in colour. In 192 the other case, greenish thoraxes presented one brown spot in the anterior part of the mesothorax that suffered a darkening process with age at the same time as the humeral stripe (Figure 2).

194 In the laboratory, adult damselflies presented a melanic process across maturation (Fig. S1). The 195 first signal was the appearance of a brown spot in the anterior part of the mesothorax in early mature individuals (column Mature 1 and Mature 2 for aurantiaca females in Fig. S1). This spot 197 was only seen in the field in the aurantiaca morph (Figures 1-2). Melanism continued covering the dorso-lateral thorax part of males and androchromes, forming a diagonal stripe in infuscans but if did not affect aurantiaca females. In reared males and androchromes, S8 showed melanic spots (Fig. S2). These black spots were present in immature individuals and became wider during their maturation but never completely replaced the blue colour. Gynochromes presented a wide range of colour variability in S8 but in all cases the blue colour disappeared with maturation. Black spots of S8 were wider in aurantiaca than in infuscans females. vivacity. A whitish dust appeared in dorsal parts (head, dorsal carina, coxae and in the three last 206 abdominal segments). 
Proportions in the first generation $\left(F_{1}\right)$

209 A total of 603 adults successfully emerged in the first generation from 21 Dec 2011 until 30 May

210 2012. The segregation of phenotypes was in agreement with the allele dominance $\mathrm{p}^{\mathrm{a}}>\mathrm{p}^{\mathrm{i}}>\mathrm{p}^{\mathrm{o}}$.

211 Proportions were as expected from the inheritance hypothesis, with the exception of a minority

212 of individuals, which could be the offspring of females mated multiply in the field (Table 2).

213 When offspring were composed of two colour morphs, they presented a ratio of 1:1 or 3:1 (A:I or

214 I:O). The progeny of female E produced all three phenotypes in a proportion 2:1:1 (A:I:O),

215 which is the expectation when two heterozygotes for different alleles mate. The allele $\mathrm{p}^{\mathrm{o}}$ was

216 present in at least in 27 out of 34 parental individuals (it was not possible to identify all alleles in

217 eight individuals).

218 Overall, $F_{1}$ sex-ratio (male:female) was not biased (1.01:1) (Table 2), nor were differences

219 among morphs $(\mathrm{A}=0.74: 1 ; \mathrm{I}=1.22: 1 ; \mathrm{O}=1.09: 1$; deviance ratio=1.32, $\mathrm{p}=0.304)$.

220

221

Proportions in the second generation $\left(F_{2}\right)$

222 A total of 1105 imagoes emerged from 17 April to 28 December 2012 . All $\mathrm{F}_{2}$ proportions $(\mathrm{N}=28$

223 families; Table 3) followed the expected allelic dominance except in one family (cross between

224 female 243 and male 66), that produced four unexpected androchrome offspring. All but two $\mathrm{F}_{1}$

225 crossed individuals $(\mathrm{N}=56)$ showed one $\mathrm{p}^{\mathrm{o}}$ allele (in these two cases it was not possible to

226 identify all alleles).

227 In contrast with $F_{1}$, the sex-ratio was deviated towards females in $F_{2}$ generation $(0.53: 1)$. This

228 female-biased sex-ratio occurred irrespective of maternal morph $(\mathrm{A}=0.53: 1 ; \mathrm{I}=0.61: 1 ; \mathrm{O}=$

$2290.41: 1$; deviance ratio $=0.36, \mathrm{p}=0.704)$. 
Female morph frequencies in the field

232 Table 4 shows sex-ratio and the frequency of female morphs in three populations from Sardinia.

233 In all cases the aurantiaca morph was the most common (63-87\% among mature females),

234 androchromes were $2-23 \%$, and infuscans $4-17 \%$. Two of the populations were sampled in two

235 consecutive years, showing little changes in frequencies.

236

237 Morph choice by males

238 The results of the experiment of model presentations to mature males indicated that males do not 239 discriminate between androchromes and other males, and showed preference for gynochromes

240 (Figure 3). A logistic regression indicates that model phenotype affected male behaviour $\left(\chi^{2}{ }_{3}=\right.$

$24111.65, \mathrm{p}=0.009$ ) but model identity (each one of the three individuals used per phenotype) does

$242 \operatorname{not}\left(\chi^{2}{ }_{8}=6.05, \mathrm{p}=0.642\right)$. Males showed low sexual interest in other males and androchromes,

243 without differences between these phenotypes $\left(\chi^{2}{ }_{1}=0.38, \mathrm{p}=0.538\right)$, and higher sexual interest to 244 both gynochromes, but without differences between them $\left(\chi^{2}{ }_{1}=0.22, p=0.640\right)$.

\section{Discussion}

247 Our results indicate that the colour polymorphism of I. genei is homologous to that of I. elegans 248 (Sánchez-Guillén, Van Gossum \& Cordero-Rivera, 2005) and I. graellsii (Cordero, 1990), with 249 one androchrome phenotype and two gynochrome phenotypes: infuscans and aurantiaca. The 250 allelic dominance is the same as in the cited species: androchrome > infuscans $>$ aurantiaca.

Colour morphs of I. genei and laboratory melanism 
253 In our experiments, most androchrome I. genei females had a violet thorax before sexual

254 maturation, which was indistinguishable from the colouration of the thorax of immature

255 infuscans females; a colour-change pattern that is also seen in I. elegans (Sánchez-Guillén, Van

256 Gossum \& Cordero-Rivera, 2005; Cordero-Rivera, 2015). Nevertheless, six females were pale

257 green and did not develop violet colouration, following the same ontogenetic colour changes as

258 males. This observation indicates that there are two phenotypes which mature into

259 androchromes, as previously described for I. elegans (Sánchez-Guillén, Van Gossum \& Cordero-

260 Rivera, 2005). These females were obtained in crosses where both parents had at least one

261 androchrome allele and might be homozygous for that allele, as previously suggested for $I$.

262 elegans (Sánchez-Guillén, Van Gossum \& Cordero-Rivera, 2005). In the laboratory, both males

263 and androchromes presented a green thorax as the final bright colouration in their ontogeny

264 (before becoming dark). In contrast, individuals from the field showed blue colouration when

265 mature, as is typical of I. elegans (Cordero-Rivera, 2015).

266 Mature infuscans females were olive-green in the laboratory, and some achieved a brownish

267 thorax. The other gynochrome phenotype (aurantiaca) was pinkish shortly after emergence, and

268 clearly identifiable. Nevertheless, both in the laboratory and in the field we observed that mature

269 aurantiaca females exhibit two colour variants. Some females became greenish, with

270 secondarily developed brown humeral lines, recalling the gynochrome females of some other

271 Ischnura species like I. rufostigma (Sanmartín-Villar, Zhang \& Cordero-Rivera, 2016). Other

272 aurantiaca females became brownish, like the mature colouration of the aurantiaca of $I$.

273 graellsii (Cordero-Rivera, 1987) and I. elegans (Sánchez-Guillén, Van Gossum \& Cordero-

274 Rivera, 2005). We have observed both aurantiaca variants in populations of I. graellsii in NW

275 Spain. We hypothesize that the expression of a second gene at maturity in aurantiaca females 
276 can modify a pigment pathway (see Chauhan et al., 2014) and determine these two phenotypes.

277 This possibility needs further study.

278 Our laboratory breeding produced melanic individuals (Fig. S1), which complicated morph

279 assignment. Melanism was previously found in other captive-reared damselflies in our

280 laboratory, notably in Coenagrion scitulum (Cordero, Santolamazza-carbone \& Utzeri, 1995) but

281 also in other species (Enallagma cyathigerum, Pyrrhosoma nymphula, Platycnemis latipes and

282 P. acutipennis; personal observations) although not in Ischnura (I. elegans, I. graellsii, I. hastata

283 , I. pumilio, I. rufostigma, I. saharensis; (Cordero-Rivera, 1990; Sánchez-Guillén, Van Gossum

284 \& Cordero-Rivera, 2005; Lorenzo-Carballa \& Cordero-Rivera, 2009; Sánchez-Guillén 2009

285 pers. comm.; personal observation). Similar melanic colouration in several Enallagma species

286 was assumed as an effect of the incomplete UV radiation that larvae and tenerals received under

287 captive conditions (Barnard et al., 2015). In our case, the only difference between I. genei and

288 the other species was the food supply. We fed I. genei only with Artemia nauplii during the

289 whole larval period, while in the other cases last instar larvae received a supplement of Tubifex

290 worms or adult Artemia (which has different nutrient composition). However, Barnard et al.

291 (2015) suggest that the nutritional supply cannot produce melanism. In our case, melanism only

292 appeared in old individuals while in the other cited cases the first adult colouration was affected

293 by melanism.

294 The darkening of S8 in males and androchromes (Fig. S2) was not observed in the field even in

295 old individuals. In the laboratory, eighth abdominal segment dark spots were already present in

296 immature individuals. The loss of blue colour in the final abdominal parts constitute the normal

297 maturation process of gynochromes of this species. In I. rufostigma some males and

298 androchromes present a large black spot in segment eight irrespective of age (Sanmartín-Villar, 
299 Zhang \& Cordero-Rivera, 2016). This kind of colour modification is due to a distributional

300 change that the spheres of the endoplasmic reticulum of the pigment cells suffer, which also

301 constitute the mechanism of colour change in species that show temperature-related colour

302 changes (Veron, O’Farrell \& Dixon, 1974; Prum, Cole \& Torres, 2004).

303

304

The inheritance mechanism

305 The observed proportions in our breeding followed the expected allelic dominance previously

306 found in I. graellsii (Cordero, 1990) and I. elegans (Sánchez-Guillén, Van Gossum \& Cordero-

307 Rivera, 2005). Nevertheless, five out of 15 crosses in the $F_{1}$ generation and one out of 28 crosses

308 in the $\mathrm{F}_{2}$ generation did not follow the expected allelic hierarchy. The unexpected female morphs

309 from $F_{1}$ crosses (one or two females per cross) can easily be explained by multiple paternity. The

310 parental generation females were collected from the field and likely mated several times before

311 being collected. In fact, paternity of the last male is usually not $100 \%$ in coenagrionids ( $79 \%$ of

312 the offspring was sired by the last male in Ischnura elegans (Cooper, Miller, \& Holland, 1996);

313 92-100\% in Ischnura graellsii (Cordero \& Miller, 1992); and 95\% in Enallagma hageni (Fincke, 314 1984)).

315 The unexpected presence of four androchrome females in the offspring of aurantiaca female 243

$316\left(\mathrm{p}^{0} \mathrm{p}^{\mathrm{o}}\right)$ and male $66\left(\mathrm{p}^{\mathrm{i}} \mathrm{p}^{\mathrm{o}}\right)$ (Table 3$)$ could be explained by: (i) a mislabelled container during

317 larval breeding, (ii) a mistake in morph identification, or (iii) an unknown genetic mechanism.

318 We are confident that all larvae were correctly assigned to their family because individuals were

319 followed from their isolation in the larval stage until their death, including the mating process,

320 and therefore no unnoticed matings could have occurred. We tried to check the possibility of

321 mislabelled larvae using a paternity test with microsatellites but the ambiguity of genetic results 
322 did not allow us to confirm the family of origin of these problematic specimens. However, the

323 genetic results were compatible with the presumed family of origin. We also think that morph

324 identification was correct, even if the melanism somewhat obscured some cues. Morph

325 identification was done in a conservative way, so that females were only assigned to a morph

326 when no doubts existed (in fact some could not be identified; see A/I column in Table 2).

327 Androchrome and infuscans females were mainly classified by the extent and persistence of S8

328 blue colouration. Melanism affected S8 colouration. However, while all infuscans females lost

329 their blue colouration at around 6 days of age, androchromes presented black marks in the

330 middle of the blue spot at around 15 days of age and never lost all the blue colour. Photographs

331 taken along the individual maturation suggest that these four females were correctly identified as

332 androchromes. Exceptional females with intermediate colours between androchrome and

333 infuscans morphs were observed in the field (one individual in I. graellsii (Cordero, 1992) and

334 another in I. elegans; personal observation). It is therefore possible that the unexpected

335 "androchrome" females in the progeny of female 243 are the result of an unknown genetic

336 mechanism, producing an intermediate phenotype, and do not invalidate our inheritance

337 hypothesis.

338 We found that the sex-ratio of our second generation was female biased although we employed

339 the same breeding methodology in both generations. As in Bots et al. (2010), our experiment

340 exclusively employed Artemia as larval food. Bots et al. (2010) experienced problems with larval

341 survivorship and adult maturation. The parental stress hypothesis proposes that females subjected

342 to low quality food intake produce maladaptive maternal effects in offspring (Rossiter, 1991,

343 1996; Vijendravarma, Narasimha \& Kawecki, 2010) affecting egg quality and/or embryo or

344 larval survivorship. In our case, the preponderance of females in our second generation suggests 
345 that male larvae may have been more susceptible to maternal effects due to the differences

346 between sexes in larval activity and/or time needed to emerge (Debecker et al., 2016), or were

347 more susceptible to cannibalism during early larval development (before they were isolated).

The maintenance of colour morphs

350 The maintenance of female colour polymorphism in odonates, and particularly in Ischnura, has

351 been intensively discussed in recent years (e.g. Takahashi et al., 2010; Iserbyt et al., 2013;

352 Sánchez-Guillén et al., 2013b; Le Rouzic et al., 2015). Several hypotheses have been proposed

353 based on frequency- and density-dependent selection. In one hand, some authors propose that

354 male-mimicry by androchromes is at the centre of the maintenance mechanism because they

355 avoid male harassment in high male densities but loss mating opportunities when males are

356 scarce (Robertson, 1985; Hinnekint, 1987). In the other hand,other authors suggest that males

357 learn to recognize as female the commonest morph in the population (Fincke, 2004). Recent

358 studies indicate that both mimicry and learning are involved in the maintenance of female colour

359 polymorphism in odonates (Sánchez-Guillén et al., 2013a). The data available for I. genei are not

360 enough for a comprehensive discussion and therefore we will concentrate on whether male-

361 mimicry is likely to have a main role or not in this species.

362 The experiment of models presentation clearly demonstrated that most males do not recognize

363 androchromes as potential mates, showing a clear preference for gynochromes (52\% of sexual

364 response versus $11 \%$ for androchromes). Therefore, the pre-requisites for the male-mimicry

365 hypothesis (Robertson, 1985) are held. It is important to consider that this experiment was done 366 on a population where androchromes were only $16 \%$ (Table 4 ). If males learn to prefer the most

367 common morph, then we expect a clear preference for aurantiaca females $(76 \%$ in the 
368 population). Nevertheless, we found that males showed similar preference for the rarest

369 infuscans (8\%) and the most common aurantiaca. This suggests that males do not discriminate

370 between both gynochrome females (see Xu et al., 2014). We hypothesize that mature aurantiaca

371 and infuscans females are essentially undistinguishable for males. Further experiments with

372 models in populations with contrasting frequencies would be illuminating.

373 We did not find differences in fecundity between female morphs as in previous studies on other 374 species (Bots et al., 2010; as Barnard et al., 2015; Galicia-Mendoza, 2015 between others).

375 However, other studies (Svensson et al., 2005; Takahashi \& Watanabe, 2010) showed

376 differences in fecundity among morphs. We found a trend in fertility that suggests a higher value

377 in aurantiaca females. If that trend were real, it could explain the preponderance of aurantiaca

378 females in both field and laboratory conditions. Female coenagrionids maximize their

379 reproductive success by minimizing inter-clutch interval rather than maximizing clutch size both 380 in the field (Banks \& Thompson, 1987) and the laboratory (Cordero, 1991). This suggests that 381 fecundity/fertility differences between ovipositions performed in a single day might be

382 biologically irrelevant if morphs differ mainly in lifetime number of clutches (Cordero, 1994) or 383 if their follow different strategies to lay a different number of eggs through time (R.A. Sánchez384 Guillén, pers. comm.). Data on the frequencies of female morphs in other populations and an 385 estimation of lifetime fecundity under field conditions are needed to model the maintenance of 386 this polymorphism in I. genei.

387 In conclusion, our results suggest a common allelic dominance system in the European Ischnura 388 species. In addition, we found that the male-mimicry hypothesis is the best explanation for the 389 maintenance of polymorphism in I. genei. This opens the possibility that colour polymorphism is 
390 in fact an array of different phenomena, and suggest that a single-common- explanation is

391 unlikely to be applicable to all species.

392

393 Acknowledgements

394 Thanks to Dalia Ivette Galicia-Mendoza and María Olalla Lorenzo-Carballa for their advice and

395 help with the laboratory rearing and for their ideas and participation in the construction of the

396 new rearing structures. Thanks to Genaro da Silva-Méndez and Rosa Ana Sánchez-Guillén for

397 their support during the genomic analyses. Thanks also for the comments and corrections

398 performed by RASG, Clint Kelly, Jacek Radwan and an anonymous reviewer. Austin Kent

399 Moore and Conor Higgins improved our English.

400

401

402

403

404

\section{References}

Andrés JA, Cordero A. 1999. The inheritance of female colour morphs in the damselfly Ceriagrion tenellum (Odonata, coenagrionidae). Heredity 82:328-35. DOI:

Banks MJ, Thompson DJ. 1987. Lifetime reproductive success of females of the damselfly Coenagrion puella. Journal of Animal Ecology 56:815-832.

407

408

409

410

411 10.1038/sj.hdy.6884930.

Barnard A, Fincke OM, Shields M, Xu M. 2015. Melanic individuals in color polymorphic Enallagma damselflies result from phenotypic, not genetic, variation. International Journal of Odonatology 18:3-14. DOI: 10.1080/13887890.2014.967316.

Bots J, van Dongen S, de Bruyn L, van Houtte N, Van Gossum H. 2010. Clutch size and reproductive success in a female polymorphic insect. Evolutionary Ecology 24:1239-1253. 
DOI: $10.1007 / \mathrm{s} 10682-010-9362-9$.

413 Boudout, JP, Kalkman VJ (Eds.). 2015. Atlas of the European dragonflies and damselflies.

$414 \quad$ KNNV-uitgeverij, Netherlands.

415 Chauhan P, Hansson B, Kraaijeveld K, de Knijff P, Svensson EI, Wellenreuther M. 2014. De novo transcriptome of Ischnura elegans provides insights into sensory biology, colour and vision genes. BMC genomics 15:808. DOI: 10.1186/1471-2164-15-808.

418

419

420

421

422

423

424

425

426

427

Cooper G, Miller PL, Holland PW. 1996. Molecular genetic analysis of sperm competition in the damselfly Ischnura elegans (Vander Linden). Proceedings of the Royal Society B 263:1343-1349. DOI: 10.1098/rspb.1996.0197.

Cordero A. 1990. The inheritance of female polymorphism in the damselfly Ischnura graellsii (Rambur) (Odonata: Coenagrionidae). Heredity 64:341-346.

Cordero A. 1991. Fecundity in Ischnura graellsii (Rambur) in the laboratory (Zygoptera: Coenagrionidae). Odonatologica 20:37-44.

Cordero A. 1992. Morphological variability, female polymorphism and heritability of body length in Ischnura graellsii (Rambur) (Zygoptera: Coenagrionidae). Odonatologica 21:409419.

Cordero A. 1994. Inter-clutch interval and number of ovipositions in females of the damselfly Ischnura graellsii (Odonata: Coenagrionidae). Etología 4:103-106.

Cordero A, Miller PL. 1992. Sperm transfer, displacement and precedence in Ischnura graellsii (Odonata: Coenagrionidae). Behavioral Ecology and Sociobiology 30:261-267. 
432 Cordero A, Santolamazza-Carbone S, Utzeri C. 1995. Male disturbance, repeated insemination

433 and sperm competition in the damselfly Coenagrion scitulum (Zygoptera: Coenagrionidae). $434 \quad$ Animal Behaviour 49:437-449.

435 Cordero A, Andrés JA. 1996. Colour polymorphism in odonates: females that mimic males?

436 Journal of the British Dragonfly Society 12:50-60.

437 Cordero A, Santolamazza-Carbone S, Utzeri C. 1998. Mating opportunities and mating costs are 438 reduced in androchrome female damselflies, Ischnura elegans (Odonata). Animal behaviour $43955: 185-97$. DOI: 10.1006/anbe.1997.0603.

440 Cordero-Rivera A. 1987. Estructura de población en Ischnura graellsii Rambur, 1842 (Zygop. 441 Coenagrionidae). Boletín de la Asociación Española de Entomología 11:269-286.

442 Cordero-Rivera A. 1990. The inheritance of female polymorphism in the daselfly Ischnura $443 \quad$ graellsii. Heredity 64:341-346.

Cordero-Rivera A. 2015. El género Ischnura en España y Portugal: guía de identificación a partir 445 de fotografías. Rola 6:37-58.

Debecker S, Sanmartín-Villar I, de Guinea-Luengo M, Cordero-Rivera A, Stoks R. 2016. Integrating the pace-of-life syndrome across species, sexes and individuals: covariation of life history and personality under pesticide exposure. Journal of Animal Ecology 85:726-

Dumont HJ. 2013. Phylofeniy of the genus Ischnura with emphasis on the old world taxa (Zygoptera: Coenagrionidae). Odonatologica 42:301-308.

452 Fincke OM. 1984. Sperm competition in the damselfly Enallagma hageni Walsh (Odonata: 
453

454

455

456

457

458

459

460

461

462

463

464

465

466

467

468

469

470

471

472

Coenagrionidae): benefits of multiple mating to males and females. Behavioral Ecology and Sociobiology 14:235-240. DOI: 10.1007/BF00299623.

Fincke OM. 2004. Polymorphic signals of harassed female odonates and the males that learn them support a novel frequency-dependent model. Animal Behaviour 67:833-845. DOI: 10.1016/j.anbehav.2003.04.017.

Fincke OM, Jödicke R, Paulson DR, Schultz TD, Dennis R, Schultz TD, Paulson DR. 2005. The evolution and frequency of female color morphs in Holarctic Odonata: why are male-like females typically the minority? International Journal of Odonatology 8:183-212. DOI: $10.1080 / 13887890.2005 .9748252$.

Ford EB. 1957. Polymorphism in plants, aimals and man. Nature 180:1315-1319.

Galicia-Mendoza DI. 2015. Estrategias reproductoras en la damisela Ischnura graellsii y evolución genital en los Zygoptera (Odonata). D. Phil. Thesis, Universidade de Vigo.

Hinnekint BON. 1987. Population dynamics of Ischnura E. elegans (Vander Linden) (Insecta: Odonata) with special reference to morphological colour changes, female polymorphism, multiannual cycles and heir influence on behaviour. Hydrobiologia 146:3-31.

Iserbyt A, Bots J, Van Gossum H, Sherratt TN. 2013. Negative frequency-dependent selection or alternative reproductive tactics: maintenance of female polymorphism in natural populations. BMC evolutionary biology 13:139. DOI: 10.1186/1471-2148-13-139.

Johnson C. 1964. The inheritance of female dimorphism in the damselfly, Ischnura damula. Genetics 49:513-519.

473 Johnson C. 1965. Mating and oviposition of damselflies in the laboratory. Canadian 
Johnson C. 1966. Genetics of female dimorphism in Ischnura demorsa. Heredity 21:453-459.

476 Le Rouzic A, Hansen TF, Gosden TP, Svensson EI. 2015. Evolutionary time-series analysis 477 reveals the signature of frequency-dependent selection on a female mating polymorphism. The American Naturalist 185:E000-E000. DOI: 10.1086/680982.

Lorenzo-Carballa MO, Cordero-Rivera A. 2009. Thelytokous parthenogenesis in the damselfly Ischnura hastata (Odonata, Coenagrionidae): genetic mechanisms and lack of bacterial infection. Heredity 103:377-384. DOI: 10.1038/hdy.2009.65.

Piersanti S, Rebora M, Salerno G, Cordero-Rivera A, Frati F. 2015. A method for rearing a large number of damselflies (Ischnura elegans, Coenagrionide) in the laboratory. International Journal of Odonatology 18:125-136. DOI: 10.1080/13887890.2015.1015179.

Prum RO, Cole JA, Torres RH. 2004. Blue integumentary structural colours in dragonflies (Odonata) are not produced by incoherent Tyndall scattering. 207:3999-4009.

R Core Team. 2016. R: A language and environment for statistical computing. R Foundation for Statistical Computing, Vienna, Austria. URL http://www.R-project.org/

Radwan J. 1993. The adaptive significance of male polymorphism in the acarid mite Caloglyphus berlesei. Behavioral Ecology and Sociobiology 33:201-208.

Robertson HM. 1985. Female dimorphism and mating behaviour in a damselfly , Ischnura ramburi: females mimicking males. Animal behaviour 33:805-809. 
dynamics? Oecologia 87:288-294. DOI: 10.1007/BF00325268.

495

496

497

498

499

500

501

502

503

504

505

506

507

508

509

510

511

512

513

514

Rossiter MC. 1996. Incidence and consequences of inherited environmental effects. Annual Review of Ecology and Systematics 27:451-476.

Roulin A, Bize P. 2007. Sexual selection in genetic colour-polymorphic species: A review of experimental studies and perspectives. Journal of Ethology 25:99-105. DOI: 10.1007/s10164-006-0006-z.

Sánchez-Guillén RA, Van Gossum H, Cordero-Rivera A. 2005. Hybridization and the inheritance of female colour polymorphism in two ischnurid damselflies (Odonata: Coenagrionidae). Biological Journal of the Linnean Society 85:471-481. DOI: 10.1111/j.1095-8312.2005.00506.x.

Sánchez-Guillén RA, Hansson B, Wellenreuther M, Svensson EI, Cordero-Rivera A. 2011. The influence of stochastic and selective forces in the population divergence of female colour polymorphism in damselflies of the genus Ischnura. Heredity 107:513-522. DOI: 10.1038/hdy.2011.36.

Sánchez-Guillén RA, Hammers M, Hansson B, Van Gossum H, Cordero-Rivera A, GaliciaMendoza DI, Wellenreuther M. 2013a. Ontogenetic shifts in male mating preference and morph-specific polyandry in a female colour polymorphic insect. BMC Evolutionary Biology 13:116. DOI: 10.1186/1471-2148-13-116.

Sánchez-Guillén RA, Martínez-Zamilpa SMJ, Jiménez-Cortés JG, Forbes MRL, CórdobaAguilar A. 2013b. Maintenance of polymorphic females: do parasites play a role? Oecologia 171:105-13. DOI: 10.1007/s00442-012-2388-7. 
515 Sánchez-Guillén RA, Córdoba-Aguilar A, Cordero-Rivera A, Wellenreuther M. 2013c. Genetic

516 divergence predicts reproductive isolation in damselflies. Journal of evolutionary biology

517 27:76-87. DOI: 10.1111/jeb.12274.

518 Sanmartín-Villar I, Zhang H, Cordero-Rivera A. 2016. Colour polymorphism and ontogenetic

519 colour changes in Ischnura rufostigma (Odonata: Coenagrionidae). Odonatologica 45(1520 2):77-86.

521 Svensson EI, Abbott J, Härdling R. 2005. Female polymorphism, frequency dependence, and 522 rapid evolutionary dynamics in natural populations. American Naturalist 165:567-576. 523 DOI: $10.1086 / 429278$.

524 Takahashi Y, Yoshimura J, Morita S, Watanabe M. 2010. Negative frequency-dependent 525 selection in female color polymorphism of a damselfly. Evolution 64:3620-3628. DOI: $526 \quad 10.1111 / \mathrm{j} .1558-5646.2010 .01083 . x$.

527 Takahashi Y, Watanabe M. 2010. Morph-specific fecundity and egg size in the female528 dimorphic damselfly Ischnura senegalensis. Zoological science 27:325-329. DOI: $529 \quad 10.2108 /$ zsj.27.325.

530 Takahashi Y, Kagawa K, Svensson EI, Kawata M. 2014. Evolution of increased phenotypic 531 diversity enhances population performance by reducing sexual harassment in damselflies. $532 \quad$ Nature communications 5:4468. DOI: 10.1038/ncomms5468.

533 Van Gossum H, Sánchez-Guillén R, Cordero Rivera A. 2003. Observations on rearing 534 damselflies under laboratory conditions. Animal Biology 53(1):37-45. DOI:

$535 \quad 10.1163 / 157075603769682567$ 
536 Van Gossum H, Sherratt TN, Cordero-Rivera A. 2008. The evolution of sex-limited colour 537 polymorphisms. In: Córdoba-Aguilar A. Dragonflies: model organisms for ecological and 538 evolutionary studies. Oxford: Oxford University Press, 219-229.

539 Van Gossum H, Bots J, Van Heusden J, Hammers M, Huyghe K, Morehouse NI. 2011.

540 Reflectance spectra and mating patterns support intraspecific mimicry in the colour 541 polymorphic damselfly Ischnura elegans. Evolutionary Ecology 25:139-154. DOI: $542 \quad 10.1007 / \mathrm{s} 10682-010-9388-\mathrm{z}$.

543 Veron JEN, O'Farrell AF, Dixon B. 1974. The fine structure of odonata chromatophores. Tissue $544 \quad \&$ Cell 6:613-626.

545 Vijendravarma RK, Narasimha S, Kawecki TJ. 2010. Effects of parental larval diet on egg size 546 and offspring traits in Drosophila. Biology letters 6:238-241. DOI: 10.1098/rsbl.2009.0754.

547 VSN International (2015). GenStat for Windows 18th Edition. VSN International, Hemel $548 \quad$ Hempstead, UK. Web page: GenStat.co.uk

549 Xu M, Cerreta AL, Schultz TD, Fincke OM. 2014. Selective use of multiple cues by males 550 reflects a decision rule for sex discrimination in a sexually mimetic damselfly. Animal 551 Behaviour 92:9-18. DOI: DOI 10.1016/j.anbehav.2014.03.016. 


\section{Table $\mathbf{1}$ (on next page)}

Results of the egg clutches obtained from field-collected females

Table 1. Results of the egg clutches obtained from field-collected females from Riu Mannu (Tula, Sassari, Sardinia - Italy). Hatching time: number of days between oviposition and first hatch; Fecundity: total number of eggs laid by each female. Values are mean $\pm \mathrm{SE}$. 


\begin{tabular}{|ccccc|}
\hline P females & Hatching time (days) & Fecundity & Unfertile eggs & Fertility (\%) \\
\hline Androchromes & & & & \\
\hline A & 14 & 78 & 22 & 71.79 \\
B & 12 & 174 & 69 & 60.34 \\
C & 12 & 217 & 15 & 93.09 \\
D & 14 & 188 & 38 & 79.79 \\
E & 12 & 135 & 15 & 88.89 \\
F & 12 & 138 & 23 & 83.33 \\
\hline Total & $12.7 \pm 0.42$ & $155.0 \pm 19.92$ & $30.3 \pm 8.46$ & $79.5 \pm 4.87$ \\
\hline infuscans & & & & \\
\hline G & 14 & 245 & 17 & 93.06 \\
H & 14 & 145 & 44 & 69.66 \\
I & 14 & 231 & 20 & 91.34 \\
J & 14 & 373 & 15 & 95.98 \\
K & 14 & 83 & 49 & 40.96 \\
\hline Total & $14.0 \pm 0.00$ & $215.4 \pm 49.21$ & $29.0 \pm 7.23$ & $78.2 \pm 10.41$ \\
\hline
\end{tabular}

\section{aurantiaca}

\begin{tabular}{|ccccc|}
\hline L & 17 & 185 & 74 & 60.00 \\
$\mathrm{M}$ & 14 & 228 & 6 & 97.37 \\
$\mathrm{~N}$ & 12 & 337 & 3 & 99.11 \\
$\mathrm{O}$ & 12 & 114 & 2 & 98.25 \\
$\mathrm{P}$ & 9 & 175 & 1 & 99.43 \\
$\mathrm{Q}$ & 12 & 97 & 6 & 93.81 \\
$\mathrm{R}$ & 9 & 272 & 0 & 100.00 \\
$\mathrm{~S}$ & 9 & 259 & 47 & 81.85 \\
$\mathrm{~T}$ & 14 & 147 & 3 & 97.96 \\
\hline Total & $12.0 \pm 0.91$ & $201.6 \pm 26.31$ & $15.8 \pm 8.77$ & $92.0 \pm 4.41$ \\
\hline Total average & $12.7 \pm 0.45$ & $191.1 \pm 17.92$ & $23.5 \pm 5.05$ & $84.8 \pm 3.68$ \\
\hline
\end{tabular}


1 


\section{Table 2 (on next page)}

The segregation of female colour morphs in the $F_{1}$ generation

Table 2. The segregation of female colour morphs in the $F_{1}$ generation. $\$ \mathrm{P}$ : females from the field; Parental genotypes: alleles of each progenitor (female and male); $q F_{1}$ : number of $F_{1}$ females; Observed: number of $F_{1}$ identified females by morph and percentage in respect to the total number of females of the same cross (between brackets); Expected: percentages expected under the allelic order of dominance $p^{a}>p^{i}>p^{0}$. Observed and expected frequencies were compared with a $\boldsymbol{\chi}^{2}$ test, and the associated $p$-value is presented. $(*)$ Possible progeny of a second mate in the field (these values were not included in the calculation of proportions). 


\begin{tabular}{|c|c|c|c|c|c|c|c|c|c|c|c|c|}
\hline \multirow[t]{2}{*}{ q $\mathrm{P}$} & \multicolumn{2}{|c|}{$\mathrm{P}$ genotypes } & \multirow{2}{*}{$\begin{array}{c}\text { Sex ratio } \\
(\widehat{\jmath}:+\circ)\end{array}$} & \multirow[t]{2}{*}{ o $\mathrm{F}_{1}$} & \multicolumn{3}{|c|}{ Observed $(\mathrm{N}$ and $\%)$} & \multicolumn{3}{|c|}{ Expected (\%) } & & \multirow[t]{2}{*}{$\mathrm{p}$} \\
\hline & o & $\hat{0}$ & & & $\mathrm{~A}$ & I & $\mathrm{O}$ & A & I & $\mathrm{O}$ & & \\
\hline
\end{tabular}

Androchrome

\begin{tabular}{|c|c|c|c|c|c|c|c|c|c|c|c|c|}
\hline $\mathrm{B}$ & $\mathrm{p}^{\mathrm{a}} \mathrm{p}^{\mathrm{o}}$ & $\mathrm{p}^{\mathrm{a}} \mathrm{p}^{\mathrm{a}}$ & 0.14 & 7 & $\begin{array}{c}6 \\
(85.7)\end{array}$ & $\begin{array}{c}0 \\
(0)\end{array}$ & $\begin{array}{c}1^{*} \\
(14.3)\end{array}$ & 100 & 0 & 0 & & \\
\hline $\mathrm{C}$ & $\mathrm{p}^{\mathrm{a}} \mathrm{p}^{\mathrm{o}}$ & $\mathrm{p}^{\mathrm{a}} \mathrm{p}^{\mathrm{o}}$ & 0.48 & 31 & $\begin{array}{c}25 \\
(80.6)\end{array}$ & $\begin{array}{c}0 \\
(0)\end{array}$ & $\begin{array}{c}6 \\
(19.4)\end{array}$ & 75 & 0 & 25 & 0.00 & 1.00 \\
\hline $\mathrm{D}$ & $\mathrm{p}^{\mathrm{a}} \mathrm{p}^{\mathrm{o}}$ & $\mathrm{p}^{\mathrm{o}} \mathrm{p}^{\mathrm{o}}$ & 0.84 & 19 & $\begin{array}{c}9 \\
(47.4)\end{array}$ & $\begin{array}{c}0 \\
(0)\end{array}$ & $\begin{array}{c}10 \\
(52.6)\end{array}$ & 50 & 0 & 50 & 0.05 & 0.819 \\
\hline $\mathrm{E}$ & $\mathrm{p}^{\mathrm{a}} \mathrm{p}^{\mathrm{o}}$ & $\mathrm{p}^{\mathrm{i}} \mathrm{p}^{\mathrm{o}}$ & 1.36 & 14 & $\begin{array}{c}8 \\
(57.1)\end{array}$ & $\begin{array}{c}3 \\
(21.4)\end{array}$ & $\begin{array}{c}3 \\
(21.4)\end{array}$ & 50 & 25 & 25 & 0.19 & 0.665 \\
\hline
\end{tabular}

\section{infuscans}

\begin{tabular}{|c|c|c|c|c|c|c|c|c|c|c|c|c|}
\hline $\mathrm{G}$ & $\mathrm{p}^{\mathrm{i} / 0} \mathrm{p}^{\mathrm{i}}$ & $\mathrm{p}^{\mathrm{i} / 0} \mathrm{p}^{\mathrm{i}}$ & 1.42 & 31 & $\begin{array}{c}1^{*} \\
(3.2)\end{array}$ & $\begin{array}{c}29 \\
(93.5)\end{array}$ & $\begin{array}{c}0 \\
(0)\end{array}$ & 0 & 100 & 0 & & \\
\hline $\mathrm{H}$ & $\mathrm{p}^{\mathrm{i}} \mathrm{p}^{\mathrm{o}}$ & $\mathrm{p}^{\mathrm{i} / \mathrm{o}} \mathrm{p}^{\mathrm{o}}$ & 0.38 & 8 & $\begin{array}{c}0 \\
(0)\end{array}$ & $\begin{array}{c}2 \\
(25.0)\end{array}$ & $\begin{array}{c}6 \\
(75.0)\end{array}$ & 0 & 50 & 50 & 2.00 & 0.157 \\
\hline $\mathrm{I}$ & $\mathrm{p}^{\mathrm{i}} \mathrm{p}^{\mathrm{o}}$ & $\mathrm{p}^{\mathrm{i}} \mathrm{p}^{\mathrm{o}}$ & 0.67 & 9 & $\begin{array}{c}0 \\
(0)\end{array}$ & $\begin{array}{c}6 \\
(66.7)\end{array}$ & $\begin{array}{c}3 \\
(33.3)\end{array}$ & 0 & 75 & 25 & 0.00 & 1.00 \\
\hline $\mathrm{J}$ & $\mathrm{p}^{\mathrm{i}} \mathrm{p}^{\mathrm{o}}$ & $\mathrm{p}^{\mathrm{o}} \mathrm{p}^{\mathrm{o}}$ & 2.17 & 6 & $\begin{array}{c}1^{*} \\
(16.7)\end{array}$ & $\begin{array}{c}2 \\
(33.3)\end{array}$ & $\begin{array}{c}3 \\
(50)\end{array}$ & 0 & 50 & 50 & 0.00 & 1.00 \\
\hline
\end{tabular}

\begin{tabular}{|c|c|c|c|c|c|c|c|c|c|c|c|c|}
\hline $\mathrm{L}$ & $\mathrm{p}^{0} \mathrm{p}^{\mathrm{o}}$ & $\mathrm{p}^{\mathrm{i}} \mathrm{p}^{\mathrm{o}}$ & 1.5 & 6 & $\begin{array}{c}0 \\
(0)\end{array}$ & $\begin{array}{c}3 \\
(50.0)\end{array}$ & $\begin{array}{c}3 \\
(50.0)\end{array}$ & 0 & 50 & 50 & 0.00 & 1.00 \\
\hline $\mathrm{M}$ & $\mathrm{p}^{\mathrm{o}} \mathrm{p}^{\mathrm{o}}$ & $\mathrm{p}^{\mathrm{o}} \mathrm{p}^{\mathrm{o}}$ & 1.31 & 14 & $\begin{array}{c}0 \\
(0)\end{array}$ & $\begin{array}{c}1^{*} \\
(7.14)\end{array}$ & $\begin{array}{c}13 \\
(92.9)\end{array}$ & 0 & 0 & 100 & & \\
\hline $\mathrm{N}$ & $\mathrm{p}^{0} \mathrm{p}^{\mathrm{o}}$ & $\mathrm{p}^{\mathrm{o}} \mathrm{p}^{\mathrm{o}}$ & 0.79 & 34 & $\begin{array}{c}0 \\
(0)\end{array}$ & $\begin{array}{c}0 \\
(0)\end{array}$ & $\begin{array}{c}34 \\
(100)\end{array}$ & 0 & 0 & 100 & & \\
\hline $\mathrm{O}$ & $\mathrm{p}^{\mathrm{o}} \mathrm{p}^{\mathrm{o}}$ & $\mathrm{p}^{\mathrm{o}} \mathrm{p}^{\mathrm{o}}$ & 0.86 & 14 & $\begin{array}{c}0 \\
(0)\end{array}$ & $\begin{array}{c}2^{*} \\
(14.3)\end{array}$ & $\begin{array}{c}12 \\
(85.7)\end{array}$ & 0 & 0 & 100 & & \\
\hline $\mathrm{P}$ & $\mathrm{p}^{0} \mathrm{p}^{\mathrm{o}}$ & $\mathrm{p}^{0} \mathrm{p}^{\mathrm{o}}$ & 1.67 & 15 & $\begin{array}{c}1^{*} \\
(6.7)\end{array}$ & $\begin{array}{c}0 \\
(0)\end{array}$ & $\begin{array}{c}12 \\
(80.0)\end{array}$ & 0 & 0 & 100 & & \\
\hline $\mathrm{Q}$ & $\mathrm{p}^{\mathrm{o}} \mathrm{p}^{\mathrm{o}}$ & $\mathrm{p}^{0} \mathrm{p}^{\mathrm{o}}$ & 1.06 & 18 & $\begin{array}{c}0 \\
(0)\end{array}$ & $\begin{array}{c}0 \\
(0)\end{array}$ & $\begin{array}{c}18 \\
(100)\end{array}$ & 0 & 0 & 100 & & \\
\hline
\end{tabular}




\section{Table 3(on next page)}

The segregation of female morphs in the $F_{2}$ generation

Table 3. The segregation of female morphs in the $F_{2}$ generation. $F_{1}$ individuals' codes include an ordinal and a letter identifying the female progenitor; $\mathrm{N}$ females: total number of females whose morph was scored; $\left({ }^{*}\right)$ case where the phenotype is not expected. A/l: androchrome or infuscans females that died before maturation and could not be assigned to a morph. 


\begin{tabular}{|c|c|c|c|c|c|c|c|c|c|c|c|c|c|c|}
\hline & & $\begin{array}{c}255 \\
\mathrm{O}\end{array}$ & $\begin{array}{c}208 \\
G\end{array}$ & 0.45 & 22 & $\begin{array}{c}0 \\
(0)\end{array}$ & $\begin{array}{c}6 \\
(27.27)\end{array}$ & $\begin{array}{c}13 \\
(59.09)\end{array}$ & $\begin{array}{c}1 \\
(4.54)\end{array}$ & 0 & 50 & 50 & 1.8 & 0.180 \\
\hline & & $\begin{array}{c}268 \\
M\end{array}$ & $\begin{array}{c}66 \\
E\end{array}$ & 1.00 & 12 & $\begin{array}{c}0 \\
(0)\end{array}$ & $\begin{array}{c}4 \\
(33.33)\end{array}$ & $\begin{array}{c}5 \\
(41.67)\end{array}$ & $\begin{array}{c}1 \\
(8.33)\end{array}$ & 0 & 50 & 50 & 0.00 & 1.00 \\
\hline & & $\begin{array}{c}291 \\
\mathrm{R}\end{array}$ & $\begin{array}{c}201 \\
O\end{array}$ & 0.13 & 15 & $\begin{array}{c}0 \\
(0)\end{array}$ & $\begin{array}{c}4 \\
(26.67)\end{array}$ & $\begin{array}{c}11 \\
(73.33)\end{array}$ & & 0 & 50 & 50 & 3.27 & 0.071 \\
\hline & & $\begin{array}{c}508 \\
\mathrm{R}\end{array}$ & $\begin{array}{c}514 \\
\mathrm{G}\end{array}$ & 0.00 & 17 & $\begin{array}{c}0 \\
(0)\end{array}$ & $\begin{array}{c}7 \\
(41.18)\end{array}$ & $\begin{array}{c}10 \\
(58.82)\end{array}$ & & 0 & 50 & 50 & 0.53 & 0.467 \\
\hline & & $\begin{array}{c}333 \\
\mathrm{R} \\
\end{array}$ & $\begin{array}{c}342 \\
\mathrm{I} \\
\end{array}$ & 0.00 & 10 & $\begin{array}{c}0 \\
(0) \\
\end{array}$ & $\begin{array}{c}3 \\
(30.00) \\
\end{array}$ & $\begin{array}{c}7 \\
(70.00) \\
\end{array}$ & & 0 & 50 & 50 & 1.6 & 0.206 \\
\hline \multirow[t]{5}{*}{$\mathrm{p}^{\mathrm{o}} \mathrm{p}^{\mathrm{o}}$} & \multirow[t]{5}{*}{$p^{o} p^{o}$} & $\begin{array}{l}9 \\
J\end{array}$ & $\begin{array}{l}8 \\
O\end{array}$ & 0.75 & 12 & $\begin{array}{c}0 \\
(0)\end{array}$ & $\begin{array}{c}0 \\
(0)\end{array}$ & $\begin{array}{c}12 \\
(100)\end{array}$ & & 0 & 0 & 100 & & \\
\hline & & $\begin{array}{c}168 \\
\mathrm{P}\end{array}$ & $\begin{array}{c}192 \\
\mathrm{P}\end{array}$ & 0.75 & 16 & $\begin{array}{c}0 \\
(0)\end{array}$ & $\begin{array}{c}0 \\
(0)\end{array}$ & $\begin{array}{c}13 \\
(100)\end{array}$ & & 0 & 0 & 100 & & \\
\hline & & $\begin{array}{c}262 \\
\mathrm{~L}\end{array}$ & $\begin{array}{c}180 \\
\mathrm{P}\end{array}$ & 0.89 & 19 & $\begin{array}{c}0 \\
(0)\end{array}$ & $\begin{array}{c}0 \\
(0)\end{array}$ & $\begin{array}{c}18 \\
(100)\end{array}$ & & 0 & 0 & 100 & & \\
\hline & & $\begin{array}{c}274 \\
\mathrm{O}\end{array}$ & $\begin{array}{c}242 \\
\mathrm{P}\end{array}$ & 0.38 & 13 & $\begin{array}{c}0 \\
(0)\end{array}$ & $\begin{array}{c}0 \\
(0)\end{array}$ & $\begin{array}{c}12 \\
(100)\end{array}$ & & 0 & 0 & 100 & & \\
\hline & & $\begin{array}{c}471 \\
\mathrm{R}\end{array}$ & $\begin{array}{c}473 \\
J\end{array}$ & 0.00 & 10 & $\begin{array}{c}0 \\
(0)\end{array}$ & $\begin{array}{c}0 \\
(0)\end{array}$ & $\begin{array}{c}10 \\
(100)\end{array}$ & & 0 & 0 & 100 & & \\
\hline
\end{tabular}




\section{Table 4 (on next page)}

The frequencies of female colour morphs in three Sardinian populations of $I$. genei.

Table 4. The frequencies of female colour morphs in three Sardinian populations of I. genei. The total number of mature adult males and females is given, together with the proportion of each female morph. There are no reliable cues to distinguish androchrome and infuscans females when they are immature because both can be violet. S8B indicates females with S8 mostly blue (as in Suppl. Fig. 2I), which usually mature as androchromes, whereas S8BB refers to females with blue and black in S8 (as in Suppl. Fig. 2J), which always mature as infuscans. 
Population

\begin{tabular}{|c|c|c|c|c|c|}
\hline & & & & & \\
\hline & $\begin{array}{c}\text { Riu Foxi, Campus } \\
\text { (Villasimius, Cagliari) }\end{array}$ & $\begin{array}{l}\text { Riu Mannu, Tula } \\
\text { (Sassari) }\end{array}$ & $\begin{array}{l}\text { Riu Mannu, Tula } \\
\text { (Sassari) }\end{array}$ & $\begin{array}{c}\text { Riu de Li Saldi, Lu } \\
\text { Lamoni (Olvia Tempio) }\end{array}$ & $\begin{array}{c}\text { Riu de Li Saldi, Lu } \\
\text { Lamoni (Olvia Tempio) }\end{array}$ \\
\hline Latitude $\left({ }^{\circ} \mathrm{N}\right)$ & 39.137309 & 40.687294 & 40.687294 & 41.127444 & 41.12744 \\
\hline Longitude $\left({ }^{\circ} \mathrm{E}\right)$ & 9.489396 & 8.989478 & 8.989478 & 9.087461 & 9.087461 \\
\hline Altitude (m) & 7 & 163 & 163 & 4 & 4 \\
\hline Date & 23 Aug 2008 & 19, 24 Aug 2011 & 21, 23 Aug 2012 & 23, 26, 28 Aug 2011 & 20, 25 Aug 2012 \\
\hline Sex-ratio $(M / F)$ & 1.14 & 1.60 & 1.30 & 2.02 & 1.10 \\
\hline \multicolumn{6}{|l|}{ Mature adults } \\
\hline Males & 64 & 235 & 181 & 106 & 32 \\
\hline Females & 56 & 79 & 86 & 47 & 28 \\
\hline Androchromes & 0.232 & 0.165 & 0.163 & 0.021 & 0.107 \\
\hline infuscans & 0.143 & 0.165 & 0.081 & 0.106 & 0.036 \\
\hline aurantiaca & 0.625 & 0.671 & 0.756 & 0.872 & 0.857 \\
\hline \multicolumn{6}{|l|}{ Young adults } \\
\hline Males & - & 22 & 28 & 1 & 0 \\
\hline Females & - & 82 & 75 & 6 & 1 \\
\hline violet-S8B & - & 0.024 & 0.080 & 0.000 & 0.000 \\
\hline violet-S8BB & - & 0.098 & 0.160 & 0.500 & 0.000 \\
\hline aurantiaca & - & 0.878 & 0.760 & 0.500 & 1.000 \\
\hline
\end{tabular}
1 


\section{Figure 1}

Mature wild individuals from the field

Figure 1. Mature wild individuals of $I$. genei from Sardinan populations. No melanism was observed in the field. A: male; B: androchrome; C: infuscans; D: aurantiaca. Photos: ACR. 


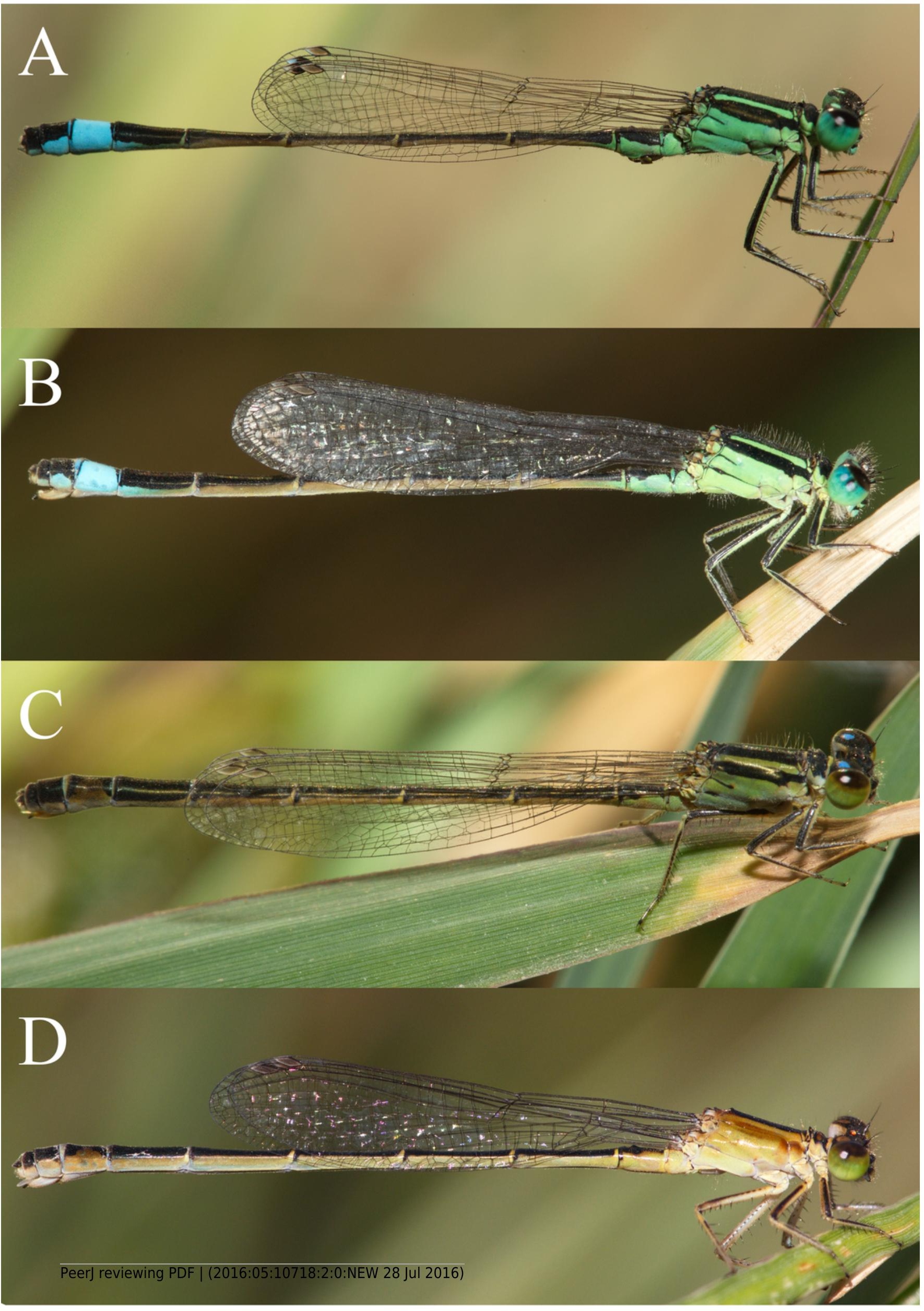




\section{Figure 2}

The ontogeny of colour changes in the female morphs

Figure 2 . The ontogeny of colour changes in the female morphs of $I$. genei. Age refers to the mean values for colour changes under laboratory conditions.

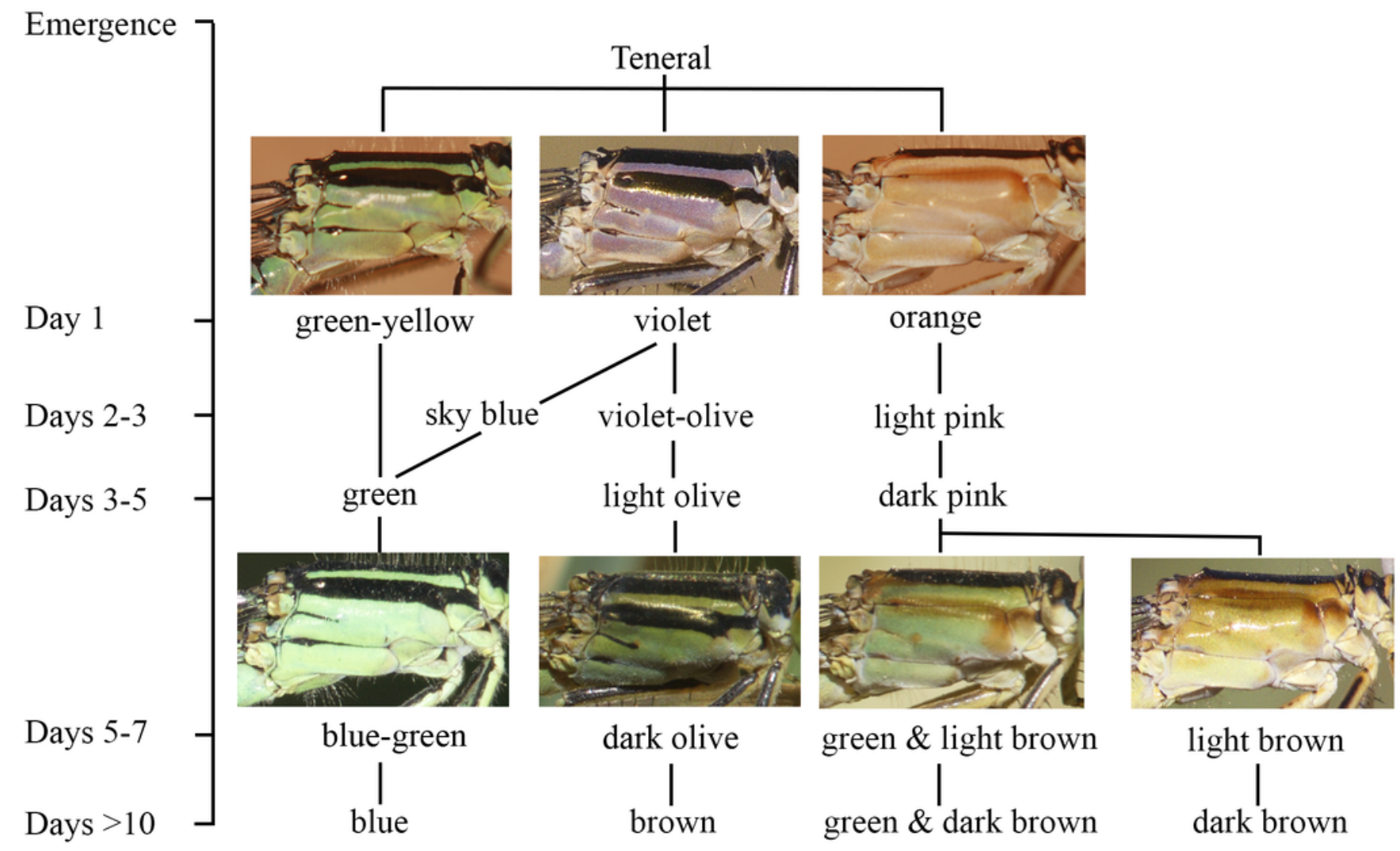


Figure 3 (on next page)

The response of $I$. genei males to live models

Figure 3. The response of $I$. genei males to live models. Males that simply approached the model were scored as not showing sexual interest. Males that tried or achieved tandem with the model were scored as showing a sexual response. The response to male and androchrome models was clearly different to both gynochrome morphs (infuscans and aurantiaca). 


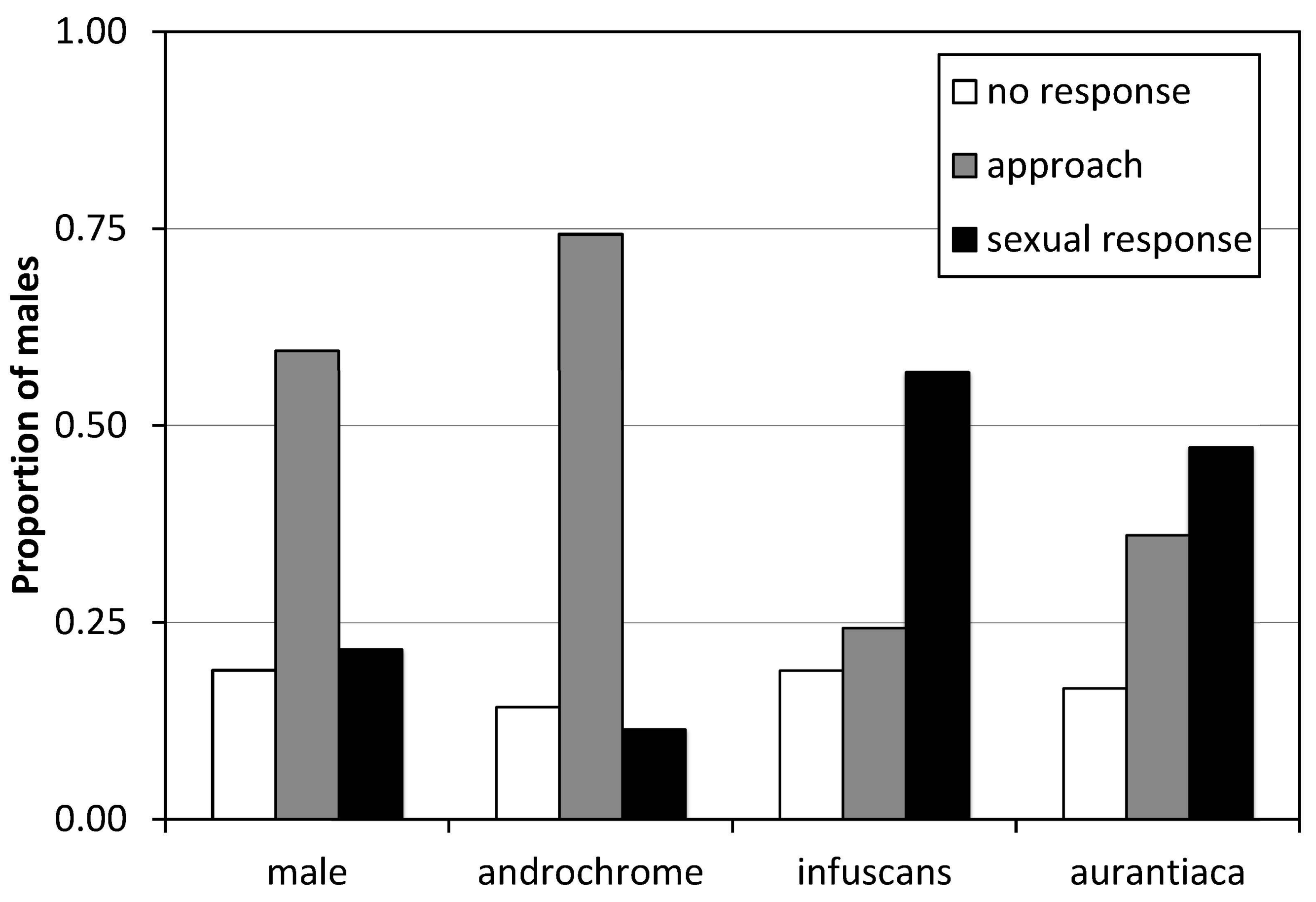

